\title{
Dual role of the Smad4/DPC4 tumor suppressor in TGF $\beta$-inducible transcriptional complexes
}

\author{
Fang Liu, Celio Pouponnot, and Joan Massagué ${ }^{1}$ \\ Cell Biology Program and Howard Hughes Medical Institute, Memorial Sloan-Kettering Cancer Center, \\ N ew York, N ew York 10021 USA
}

\begin{abstract}
Upon ligand binding, the receptors of the TGF $\beta$ family phosphorylate Smad proteins, which then move into the nucleus where they activate transcription. To carry out this function, the receptor-activated Smads 1 and 2 require association with the product of deleted in pancreatic carcinoma, locus 4 (D PC 4), Smad4. We investigated the step at which Smad4 is required for transcriptional activation. Smad4 is not required for nuclear translocation of Smads 1 or 2, or for association of Smad2 with a DNA binding partner, the winged helix protein FAST-1. Receptor-activated Smad2 takes Smad4 into the nucleus where they form a complex with FAST-1 that requires these three components to activate transcription. Smad4 contributes two functions: Through its amino-terminal domain, Smad4 promotes binding of the Smad2/Smad4/FAST-1 complex to DNA; through its carboxy-terminal domain, Smad4 provides an activation function required for Smad1 or Smad2 to stimulate transcription. The dual function of Smad4 in transcriptional activation underscores its central role in TGF $\beta$ signaling.
\end{abstract}

[Key Words: TGF $\beta$; activin; BMP; SMAD; signal transduction; transcriptional regulation; tumor suppressors]

Received August 29, 1997; revised version accepted October 3, 1997.

The transformation growth factor $\beta$ (TGF $\beta$ ) family signals a wide variety of biological responses through transcriptional regulation of genes encoding critical determinants of cell fate such as cell-cycle regulators (Pietenpol et al. 1990; Hannon and Beach 1994; Datto et al. 1995; Reynisdóttir et al. 1995; Iavarone and M assagué 1997), differentiation factors (Zentella and M assagué 1992), extracellular matrix proteins (Kerr et al. 1988; Rossi et al. 1988; Keeton et al. 1991; Inagaki et al. 1994) or homeobox gene products (Huang et al. 1995). Clues about the mechanism of transcriptional regulation by the TGF $\beta$ family have been provided by the recent discovery of the SM AD proteins as direct substrates of TGF $\beta$ family receptors and mediators of receptor signals to the nucleus. The founding member of the SMAD family is the product of the Drosophila gene Mad, which was identified as being required for signal ing by the BM $P$ homolog Decapentaplegic (D pp) (Sekel sky et al. 1995). The discovery of $\mathrm{M}$ ad and the identification of nematode and vertebrate $M$ ad-rel ated gene products termed SM ADs allowed the elucidation of a signaling pathway in which receptor phosphorylated SMADs move into the nucleus to activate transcription (for review, see Derynck and Zhang 1996; Wrana and Attisano 1996; Massagué et al. 1997).

${ }^{1}$ Corresponding author.

E-MAIL j-massague@ski.mskcc.org FAX (212) 717-3298.
The members of the SM AD family contain highly conserved amino- and carboxy-terminal domains (referred to as $\mathrm{N}$ and $\mathrm{C}$ domains, or $\mathrm{MH} 1$ and $\mathrm{MH} 2$ domains, respectively), separated by a more divergent linker region. On the basis of structural and functional criteria, the SM AD family can be divided into three subgroups. One group includes those SMADs that are direct receptor substrates. The second group includes co-SMADs, or SMADs that are not direct receptor substrates, but participate in signaling by associating with receptor-activated SM ADs (for review, see Derynck and Zhang 1996; Wrana and Attisano 1996; Massagué et al. 1997). The third group includes proteins that interfere with SM AD activation and can be referred to as anti-SMADs (Hayashi et al. 1997; Topper et al. 1997).

Among the receptor-regulated SMADs, Smad1 and presumably its close homologs Smad5 and Smad9 are bone morphogenetic protein (BMP) receptor substrates and mediators of BMP signals in vertebrates (Graff et al. 1996; Hoodless et al. 1996; Lechleider et al . 1996; Liu et al. 1996; Thomsen 1996; Yingling et al. 1996; Kretzschmar et al. 1997a; Watanabe et al . 1997), whereas M ad in Drosophila (Newfeld et al. 1996; Wiersdorff et al. 1996) and Sma-2 and Sma-3 in Caenorhabditis elegans (Savage et al . 1996) mediate the actions of BM P-like factors in these organisms. Smad2 and Smad3 are substrates and mediators of related TGF $\beta$ and activin receptors in vertebrates (Baker and Harland 1996; Eppert et al. 1996; 
Graff et al. 1996; Macias-Silva et al. 1996; Zhang et al. 1996). Receptor-regulated SM ADs are phosphorylated by the receptors at the carboxy-terminal end, which typically is an $\mathrm{SS}^{\mathrm{V}} / \mathrm{M}$ S sequence (Macias-Silva et al. 1996; Kretzschmar et al. 1997a). The $\mathrm{N}$ and $\mathrm{C}$ domains of these SM ADs interact with each other, causing auto inhibition (Baker and Harland 1996; Liu et al. 1996; Hata et al. 1997), and agonist-induced phosphorylation may relieve this inhibition.

On phosphorylation of the carboxy-terminal residues, SM ADs move into the nucleus (Hoodless et al. 1996; Liu et al. 1996; N akao et al. 1997a,b) where they participate in agonist-dependent transcriptional activation as originally inferred from studies showing that Smad1 fused to the GAL4 DNA-binding domain has transcriptional activity that is regulated by BMP (Liu et al. 1996). As further evidence for a direct role of SM ADs in transcription, activin has been shown to activate the Mix. 2 homeobox gene in Xenopus by inducing the association of Smad2 with FAST-1 (Chen et al. 1996), a nuclear protein that belongs to the winged helix transcription factor family and recognizes an activin responsive element (ARE) in the Mix.2 promoter (Huang et al. 1995). This has led to a model in which receptor-activated Smad2 translocates into the nucleus where it associates with a DN A-binding protein forming a transcriptional complex (Chen et al. 1996).

Signaling by receptor-regulated SMADs requires the partici pation of a co-SM AD. The only known member of this group in vertebrates is Smad4. Smad4 has the same overall structure as the receptor-regulated SM ADs, but is more divergent and lacks the carboxy-terminal phosphorylation motif. Smad4 was origi nal ly identified as the product of the DPC 4 tumor suppressor (Hahn et al . 1996) that is mutated or deleted in a high proportion of pancreatic cancers and in a smaller proportion of other cancers (Barrett et al. 1996; Hahn et al. 1996; Kim et al. 1996; N agatake et al. 1996; Schutte et al. 1996). Inactivating missense mutations have been found both in the $\mathrm{N}$ and $C$ domains in different tumor-derived DPC 4 alleles. A similar distribution of inactivating mutations has been observed in another tumor suppressor in this family, Smad2 (Eppert et al. 1996; Riggins et al. 1996; Uchida et al. 1996). The $C$ domain of SM ADs has effector function in various biological assays (Baker and Harland 1996; Lagna et al. 1996; Liu et al. 1996) and mutations in this domain disrupt its activity (Shi et al. 1997). The crystal structure of the Smad4 C domain reveals that it is a trimer, and certain mutations disrupt the monomer interfaces of this trimer (Shi et al. 1997). Mutations in the $\mathrm{N}$ domain of Smad2 and Smad4 augment the autoinhibitory function of this domain (Hata et al. 1997) and may have additional effects (Kim et al. 1997).

A general requirement of Smad4 in TGF $\beta$ family signaling is suggested not only by the requirement of Smad4 for TGF $\beta$ responsiveness in mammalian cells (Lagna et al. 1996; Zhang et al. 1996) but also by its requirement for activin and BM $P$ responses in Xenopus embryo (Lagna et al. 1996, Zhang et al. 1997). Thus, Smad4 is a shared co-Smad, participating in both TGF $\beta$ / activin and BMP signaling pathways. Smad4 associates with Smad1 or Smad2 when these SMADs are phosphorylated by specific receptors (Lagna et al. 1996) and is required for their signaling function (Lagna et al. 1996; Zhang et al. 1996, 1997). The interaction between the receptor-regulated SMADs and Smad4 is mediated by their C domains (Hata et al. 1997; Wu et al. 1997).

Although Smad4 is recognized as a central mediator for TGF $\beta$ signaling, it was not clear which step of the SMAD-signaling pathway requires Smad4 function. In this study we made use of a Smad4-defi cient cell line and the FAST-1/Mix.2 system reconstituted in mammalian cells to investigate this problem. We show that Smad4 is not required for nuclear translocation of a receptor-activated SMAD but its association with a receptor-activated SMAD promotes binding of the SMAD complex to DNA and, furthermore, it provides an essential transcriptional activation function.

\section{Results}

Nuclear translocation of Smad1 and Smad2 does not require Smad4

To investigate which step of the TGF $\beta$ and BMP signaling pathways requires Smad4, we first determined whether ligand-dependent nuclear translocation of Smad1 and Smad2 can occur in the absence of Smad4. When expressed as amino-terminal epitope-tagged constructs in SW480.7 human colon carcinoma cells (Goyette et al. 1992), which lack Smad4 (Zhang et al. 1996), Smad1 and Smad2 were mostly cytoplasmic under basal conditions (Fig. 1A). U pon cotransfection with constitutively active BM $P$ or TGF $\beta$ receptors and treatment with BM P4 or TGF $\beta$, respectively, Smad1 or Smad2 accumulated in the nucleus (Fig. 1A). N o further increases in the nuclear local ization of Smad1 or Smad2 were detected on cotransfection of Smad4 (data not shown). These results indicate that Smad4 is not required for nuclear translocation of Smad1 or Smad2.

\section{Smad4 nuclear translocation depends on receptor activated SMADs}

Transfected Smad4 is local ized predominantly in the cytoplasm in SW480.7 cells (Fig. 1B) or COS cells (data not shown), as visualized by immunostaining via an aminoterminal Flag epitope tag. The nuclear level of FlagSmad4 was increased only slightly by BMP4 (Fig. 1C). Cotransfection with Smad1 or Smad2 had little effect on the cellular localization of Flag-Smad4 (Fig. 1C). Cotransfection of Smad1 or Smad2 (or Smad3, which is expressed at a higher level than Smad2 under these conditions), however, enabled Flag-Smad4 to accumulate in the nucleus in response to BMP4 or TGF $\beta$, respectively (Fig. 1B,C). In the absence of cotransfected Smad1, Smad2, or Smad3, the endogenous level of these proteins in SW480.7 cells may be too low to carry a detectable proportion of the overexpressed Smad4 into the nucleus in response to ligand. Because agonist-induced activation 
A
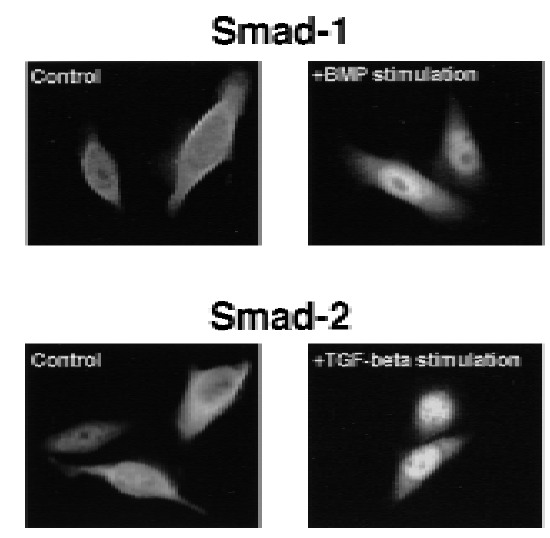

B

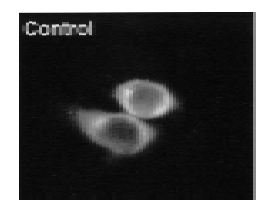

Smad-4
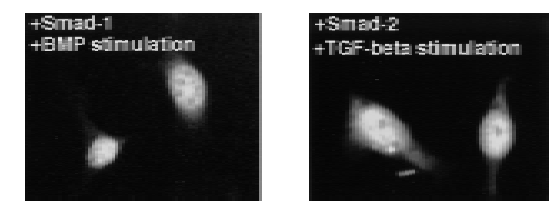

C

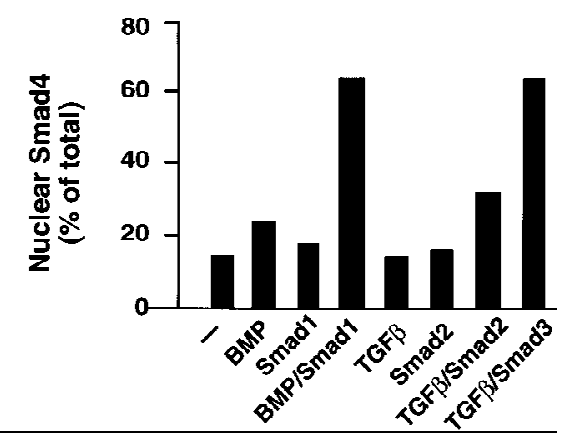

Figure 1. (A) $\mathrm{N}$ ucl ear transl ocation of Smad1 and Smad2 in the absence of Smad4. SW480.7 cells were transfected with FlagSmad1 or Flag-Smad2 and stimulated with BMP or TGF $\beta$ by cotransfection with activated BM P or TGF $\beta$ receptor plus treatment with BM P4 or TGF $\beta 1$. Immunofluorescence staining with anti-Flag antibody was then performed. After agonist stimulation, Flag-Smad1 staining was nuclear in up to $60 \%$ of the cells and Flag-Smad2 staining in up to $76 \%$ of the cells. (B) Smad4 requires a receptor-activated Smad for nucl ear translocation in response to agonists. Amino-terminal Flag-tagged Smad4 was transfected al one or with the indicated SM ADs and stimulated with BMP or TGF $\beta$ as in A. Shown are Flag immunostaining of cells transfected with Flag-Smad4 alone (control), with Smad1 and stimulated with BM P, or with Smad2 and stimulated with TGF $\beta$. (C) A quantitation of Smad4 nuclear staining under various conditions in one representative experiment. BMP and TGF $\beta$ refers to $B M P$ or TGF $\beta$ stimulation by cotransfection with activated BM P or TGF $\beta$ receptor and treatment with BM P4 or TGF $\beta 1$, respectively.

of Smad1 and Smad2 leads to their association with Smad4 (Lagna et al. 1996; Kretzschmar et al. 1997a), we surmise that the activated Smads bind Smad4 in the cytoplasm and carry it into the nucleus.
Reconstitution of a Xenopus activin/TGF $\beta$ transcriptional response in mammalian cells

To investigate whether Smad4 might be essential for the formation of a transcriptional complex, we first reconstituted, in mammalian cells, the FAST-1-dependent transcriptional response from Xenopus, which is the only example to date of a natural transcriptional complex formed in response to a TGF $\beta$ family member and involving SMADs. Activin signaling in Xenopus early embryos induces the formation of an activin response factor (ARF) that contains Smad2 and FAST-1 (Chen et al. 1996), binds to the activin response element ARE in the Mix. 2 promoter, and activates the reporter construct A 3CAT that contains three copies of the ARE (Huang et al. 1995). As shown in Figure 2, A3CAT responded to activin when cotransfected with FAST-1 but not when transfected alone into the lung epithelial cell line R1B/ L17. This response was not increased when the activin type I receptor ActR-IA was overexpressed. Overexpression of ActR-IB caused a high basal activation of A 3CAT (Fig. 2), suggesting that ActR-IB can mediate this response. Because the ActR-IB kinase domain shares $97 \%$ sequence similarity with that of the TGF $\beta$ type I receptor T $\beta$ R-I (Cárcamo et al. 1994), we tested whether A3CAT could be activated via T $\beta$ R-I. R-1B/L17 cells, which lack T $\beta R$-I but become responsive to TGF $\beta$ on transfection of this receptor (Wrana et al. 1994; WeisGarcia and M assagué 1996), showed a FAST-1- and T $\beta$ RI-dependent activation of A 3 CAT by TGF $\beta$ (Fig. 2). In a recent study, Hayashi et al. (1997) have also shown that the A3CAT reporter gene can be activated by TGF $\beta$. Because of the limited availability of activin, the remaining work was carried out by use of TGF $\beta$ as the agonist.

\section{C domains mediate the Smad2/FAST-1 interaction}

The presence of both Smad2 and FAST-1 in Xenopus ARF has been inferred from gel shift assays by use of the ARE probe (Chen et al. 1996). Consistent with the gel

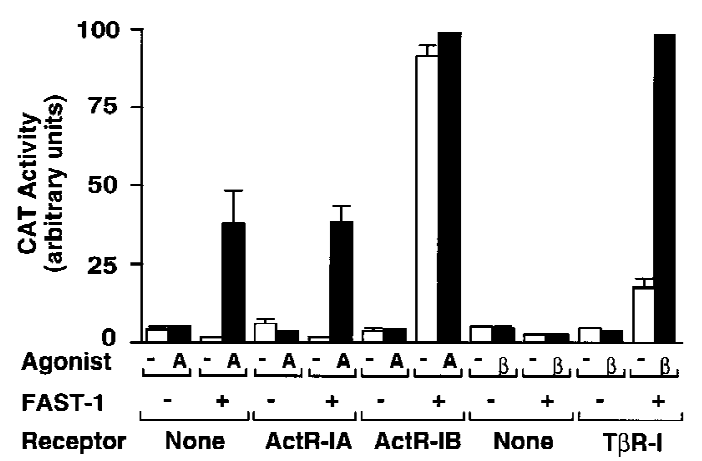

Figure 2. Reconstitution of the Mix2-FAST-1 transcriptional response in mammal ian cells. R 1B/L17 cells were cotransfected with the Mix2 reporter A 3 CAT and the indicated FAST - 1 and receptor vectors, then treated with activin $(A)$ or TGF $\beta(\beta)$. Reporter CAT activity was then determined. Data are the average \pm .D. of triplicates. 
shift result, we were able to detect a TGF $\beta$-induced Smad2-FAST-1 association in R-1B/L17 cells by coimmunoprecipitation assay (Fig. 3A). The interaction is specific because TGF $\beta$ did not induce association of Smad1 with FAST-1 (data not shown). The $C$ domain in Smad2 has effector activity that is inhibited by the $\mathrm{N}$ domain (Baker and Harland 1996; Liu et al. 1996; Hata et al. 1997). Receptor-mediated phosphorylation relieves this repression and additionally enhances the signaling function of the isolated C domain (Hata et al. 1997). In agreement with this, the isolated $\mathrm{C}$ domain of Smad2 interacted constitutively, al beit weakly, with FAST-1, and this interaction was increased by TGF $\beta$ addition (Fig. 3A). Mutation of the receptor phosphorylation sites at the carboxyl terminus of Smad2 (M acias-Silva et al. 1996; Kretzschmar et al. 1997a) prevented the binding to FAST-1 (Fig. 3A, AAMA construct). A Smad2 nonsense mutant lacking the entire phosphorylation region [Smad2(1-429)] and a phosphorylation-defective mutant

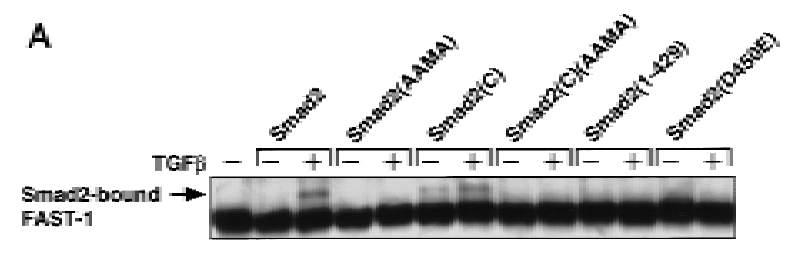

B
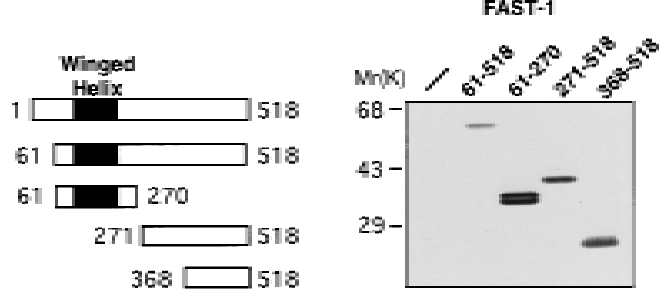

C

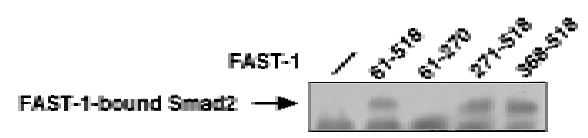

Figure 3. FAST-1 interaction with Smad2. (A) TGF $\beta$-induced FAST-1 association with Smad2. R1B/L17 cells were cotransfected with Myc-FAST -1, the indicated Flag-Smad2 derivatives, and T $\beta$ R-I for TGF $\beta$ stimulation. After incubation with or without TGF $\beta$, cell lysates were immunoprecipitated with anti-Flag antibody and the precipitates subjected to anti-M yc immunoblotting. Smad2(AAMA) contains Ser to Ala mutations in the carboxy-terminal SSMS sequence (Macias-Silva et al. 1996; Kretzschmar et al. 1997a). Smad2(C) refers to the Smad2 C domain (amino acids 248-467) (Hata et al. 1997). Smad2(1-429) and Smad2(D 450E) are tumor-derived inactive Smad2 mutants (Eppert et al. 1996). (B) FAST-1 truncation constructs and their expression (as Myc-tagged constructs) in R-1B/L17 cells, as determined by anti-M yc immunoblotting analysis of cell lysates. (Sol id rectangles) The winged hel ix DN A-binding domain (Chen et al. 1996). (C) Smad2 interaction with the FAST-1 C domain. R1B/L17 cells were cotransfected with Flag-Smad2, T $\beta R-1$, and the indicated M yc-FAST-1 derivatives. Cells were treated with TGF $\beta$ and analyzed by immunoprecipitation with anti-M yc antibody followed by anti-Flag immunoblotting.
[Smad2(D450E) (Eppert et al. 1996)] were al so unable to associate with FAST-1 (Fig. 3A). The various constructs were controlled to be expressed at comparable levels (data not shown). To map the binding region on FAST-1, we constructed a panel of Myc epitope-tagged FAST-1 deletion mutants (Fig. 3B), and found that Smad2 associates with the $\mathrm{C}$ domain but not the DNA-binding domain of FAST-1 (Fig. 3C). Thus, Smad2 can associate with FAST -1 in mammalian cells in an agonist-dependent and specific manner, and this interaction is mediated via the $C$ domains of the two proteins.

The Smad2/FAST-1 interaction does not require Smad4

To determine whether FAST -1 and Smad2 can interact with each other in a Smad4-independent manner, we analyzed the association of Smad2 and FAST-1 in SW480.7 cells. As shown in Figure 4A, TGF $\beta$ induced the formation of the Smad2/FAST-1 complex in SW 480.7 cells. The FAST -1 and Smad2 complex was unaffected when Smad4 was cotransfected (Fig. 4A). We al so observed an interaction between Smad2 and FAST-1 in the yeast two-hybrid system and in vitro (data not shown). This indicates that the interaction between Smad2 and FAST - 1 is direct and does not require Smad4.

\section{Smad4 forms a ternary complex with Smad2 and} FAST-1

In contrast to Smad2, Smad4 did not form a stable complex with FAST-1 when cotransfected as epitope-tagged constructs in SW480.7 cells (Fig. 4B). TGF $\beta$ induced the association of Smad4 and FAST-1, however, when these constructs were cotransfected with Smad2 (Fig. 4B). To determine whether Smad2, Smad4, and FAST-1 are in the same complex, COS cells were cotransfected with Flag-tagged Smad2, HA-tagged Smad4, and Myc-tagged FAST-1. Cell lysates were immunopreci pitated with Flag antibody coupled to agarose beads. Immune complexes were eluted with Flag peptide and the eluate used in a second immunoprecipitation with Myc antibody. Finally, the precipitate was analyzed by immunoblotting with HA antibody. As shown in Figure 4C, a ternary complex was detected when cells were cotransfected with all three constructs and incubated with TGF $\beta$, but not when any one construct was omitted or when TGF $\beta$ was not added. Furthermore, the TGF $\beta$-induced association of Smad2 and Smad4 (Fig. 4D) was strongly enhanced when these constructs were cotransfected with FAST-1 (Fig. 4D). Si milar results were obtained in R-1B/ L17 cells (data not shown). FAST-1 therefore appears to stabilize the Smad2-Smad4 interaction.

Smad4 promotes DNA binding and transcriptional activation by the ternary complex

To determine whether Smad4 is required for the formation of a TGF $\beta$-inducible DN A-protein complex, we assayed SW480.7 cell extracts for TGF $\beta$-inducible binding 
A

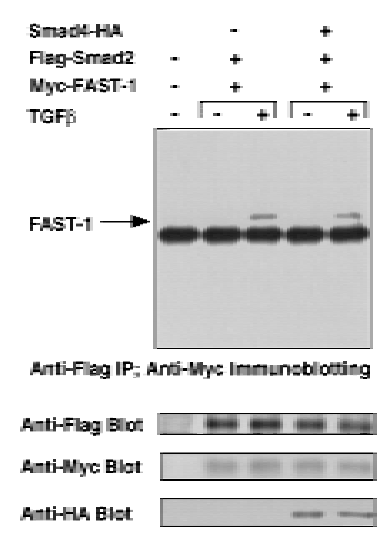

c

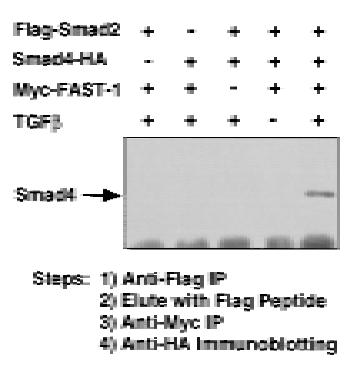

B

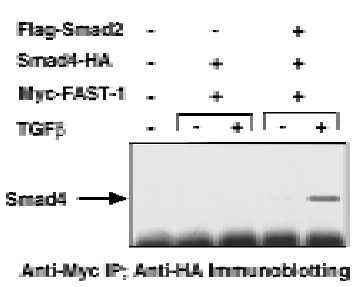

D

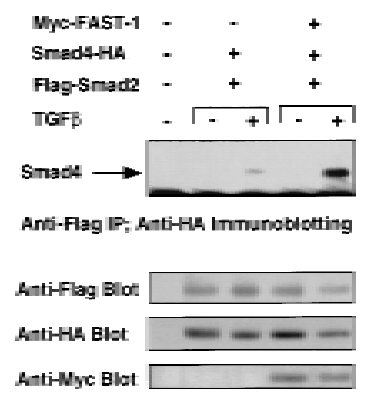

Figure 4. TGF $\beta$-induced Smad2-Smad4-FAST-1 complex. (A) Smad2 interaction with FAST-1 does not require Smad4. SW480.7 cells were cotransfected with the indicated vectors and treated with TGF $\beta$ as indicated. Cell lysates were immunoprecipitated with anti-Flag antibody and the precipitates analyzed by anti-M yc immunoblotting. (B) Smad2-dependent interaction of Smad4 with FAST-1. SW480.7 cells were transfected with M yc-FAST-1, Flag-Smad2 and HA-tagged Smad4 vectors, and treated with TGF $\beta$ as indicated. Cell lysates were immunoprecipitated with anti-M yc antibody and the precipitates analyzed by anti-HA immunoblotting. (C) Agonist-induced Smad2Smad4-FAST-1 ternary complex. COS cells were cotransfected with the indicated vectors, and T $\beta R-I$ (T204D) for TGF- $\beta$ stimulation. Cells lysates were immunoprecipitated with agarose-immobilized anti-Flag antibody. Beads were eluted with Flag peptide, and the eluate precipitated by anti-myc antibody followed by anti-HA immunoblotting. (D) FAST-1 enhances the Smad2Smad4 interaction. COS cells were cotransfected with the indicated vectors, and T $\beta R-I(T 204 D)$ for TGF $\beta$ stimulation. Cell lysates were precipitated with anti-Flag antibody and the precipitates analyzed by anti-HA immunoblotting.

activity by use of the ARE oligonucleotide probe. Nuclear extracts from cells transfected with FAST-1 al one yiel ded a small amount of M yc-FAST-1-ARE complex, which comigrated with a background band but was revealed by supershift with anti-M yc antibody (Fig. 5A; data not shown). Importantly, no TGF $\beta$-inducible AREbinding complex was detected in cells transfected with vector al one or FAST-1 al one, or Smad2 and Smad4 (Fig. $5 A$, lanes 1-6). Although FAST -1 and Smad2 can form a stable complex as shown in the coimmunoprecipitation

assay (Figs. 3A and 4A), little or no new ARE-binding complex was observed when Smad2 was cotransfected with FAST-1 in these cells (Fig. 5A, lanes 7,8). Cotransfection of Smad4 with FAST-1 yielded limited levels of binding (lanes 9,10). FAST-1, Smad2, and Smad4 transfected together, however, yielded a high basal level of binding activity that was further increased by TGF $\beta$ (lanes 11,12). We also performed the same experiment with whole cell extracts. In agreement with a previous report (Chen et al. 1996), whole cell extracts from cells transfected with FAST - 1 al one yield high level s of FAST 1-ARE complex (data not shown). Smad4 as well as Smad2, however, were requi red for formation of a TGF $\beta$ inducible ARE-binding complex (data not shown), in agreement with the results by use of nuclear extracts.

The ability of Smad4 to associate with Smad2 and FAST-1 in response to TGF $\beta$ and the requirement of Smad4 for the generation of an ARE-binding complex correlated with an essential role of Smad4 in trancriptional activation of the A 3 CAT reporter gene (Fig. 5B). Cotransfection of FAST-1 and Smad2 led to a very low level of activation of the $A$ ЗCAT reporter gene in the presence of TGF $\beta$ in SW480.7 cells. Transcriptional activation of the A 3 CAT reporter gene occurred when Smad-4 and FAST-1 were cotransfected (Fig. 5B), which is consistent with the notion that these cell s contain low level of endogenous Smad2-like activity. Cotransfection of Smad2, Smad4, and FAST-1 together led to a strong basal activation of A 3CAT that was further increased by TGF $\beta$ addition (Fig. 5B).

To establish that Myc-FAST-1, Flag-Smad2, and Smad4-HA are all in the same ARE-binding complex, we used antibodies against the epitope tags of each of these constructs to supershift the complex (Fig. 5C, lanes 7-9). Combinations of any two or all three antibodies yiel ded supershifts of progressivel y lower electrophoretic mobility (Fig. 5C, Ianes 10-13). The Flag antibody did not lead to any detectable supershift in nuclear or whole cell extracts from cells transfected with FAST -1 and Smad2 (data not shown) further indicating that the Smad2/ FAST-1 complex has little ARE-binding activity in these assays. The results indicate that the Smad2/Smad4/ FAST - 1 ternary complex binds DNA as one entity.

\section{The $\mathrm{N}$ domain of Smad4 contributes to DNA binding}

Because the isolated $\mathrm{C}$ domain of Smad4 can stably interact with Smad2 (Hata et al. 1997), we analyzed whether it can generate an ARE-binding complex together with Smad2 and FAST-1. As shown in Figure 6A, the Smad4 C domain transfected with Smad2 and FAST-1 led to an ARE-binding complex with 20-fold lower efficiency than the full-length Smad4. Furthermore, Smad4 constructs with partial or complete deletion of the $\mathrm{N}$ domain were inefficient at supporting A3CAT activation (Fig. 6B). Taken together, these observations imply that the $\mathrm{N}$ domain of Smad4 contributes to binding of the ternary complex to the ARE. In contrast, the $\mathrm{N}$ domain of Smad2 is not essential for activation of the A 3 CAT reporter gene (Fig. 6B). 
A

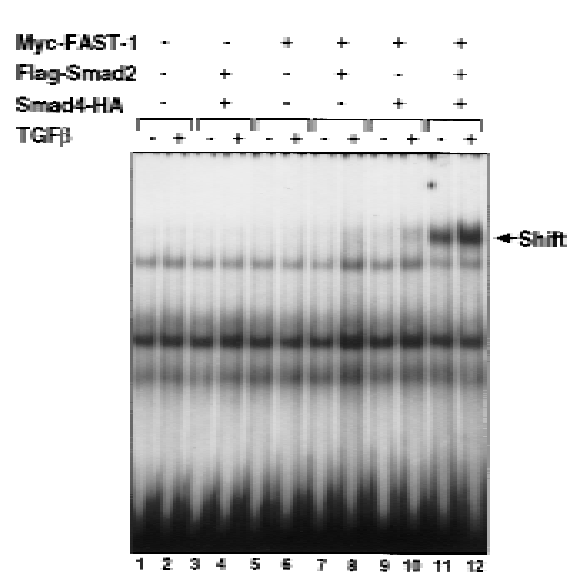

B

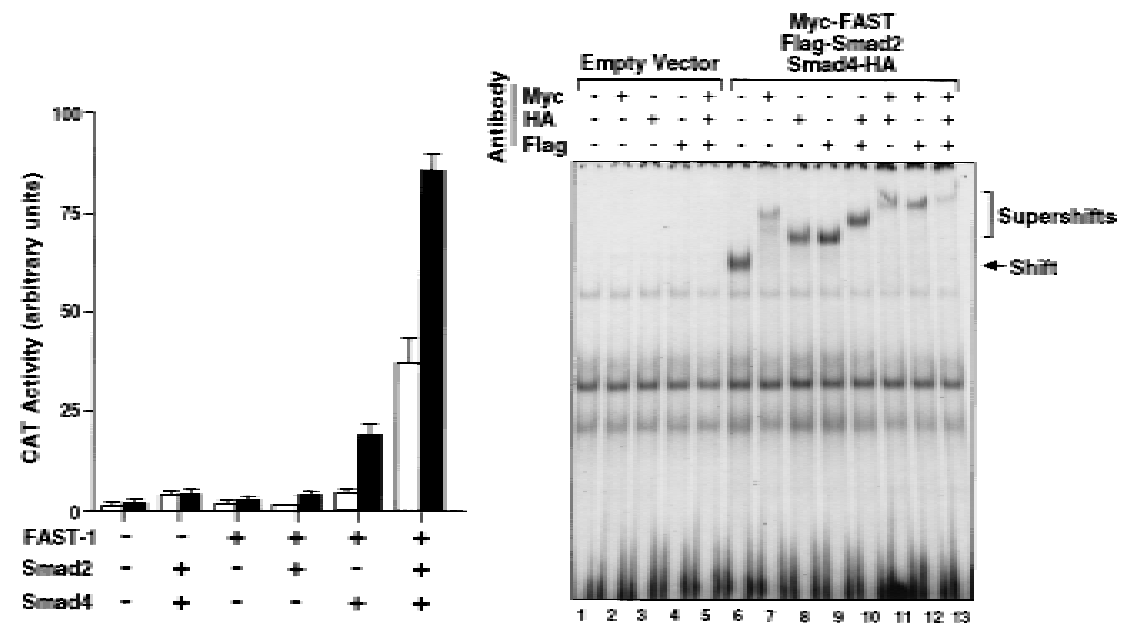

Figure 5. Smad4 is essential for the formation of a TGF $\beta$-inducible DNA-binding complex and transcriptional activation. (A) A TGF $\beta$-inducible DN A-binding complex requiring FAST-1, Smad2, and Smad4. SW480.7 cells were cotransfected with M yc-FAST-1, Flag-Smad2, and Smad4-HA and treated with TGF $\beta$ as indicated. N uclear extracts were used to perform gel mobility shift assays by use of the 50-bp ARE oligonucleotide as a probe. (B) Smad4 is essential for activation of the M ix2 reporter A3CAT. SW480.7 cells were cotransfected with the A3CAT reporter gene (Huang et al. 1995), FAST-1, Smad2, and Smad4, and treated with TGF $\beta$ ( $\square$ ) or not ( $\square$ ), as indicated. CAT activity was then analyzed. (C) FAST -1, Smad2, and Smad4 bind together to DN A. SW480.7 cells were cotransfected with the indicated vectors and treated with TGF $\beta$. Supershift assays were performed by use of nuclear extracts with the indicated antibodies individually or in various combinations.

The $C$ domain of Smad4 is required for transcriptional activation by receptor-regulated Smads

To determine whether Smad4 has additional roles in the transcriptional complex besides promoting binding to DN A, we used a transcription assay in which Smad binding to a GAL4 reporter gene is ensured by a DNA-binding domain of GAL4 fused amino-terminally to Smads. In this assay, GAL4-Smad1 (Liu et al. 1996) and GAL4Smad2 ( $F$. Liu et al., unpubl.) activate transcription in response to $B M P$ and $T G F \beta /$ activin, respectively, in $\mathrm{R} 1 \mathrm{~B} / \mathrm{L} 17$ cells that contain wild-type Smad4. To determine whether the transcription activities of GAL4Smad1 and GAL4-Smad2 are dependent on Smad4, we performed the same assay in SW480.7 cells that lack endogenous Smad4. Figure 7A shows that GAL4-Smad1 and GA L4-Smad2 had very low activity in SW480.7 cells even in the presence of ligand stimulation, but were greatly stimulated by BMP or TGF $\beta$ when cotransfected with wild-type Smad4. Importantly, the isolated C domain of Smad4 [Smad4(240-552) construct] was as effective as the full-length Smad4 in restoring agonist-induced transcriptional activation by GAL4-Smad2 (Fig. 7B) or GAL4-Smad1 (data not shown). In contrast, a Smad4 construct with a small carboxy-terminal truncation [Smad4(1-514)] was unable to rescue these responses (Fig. 7B). Taken together, these results indicated that the transcriptional activity of Smad1 and Smad2 is dependent on Smad4, and the C domain of Smad4 provides this activity.

\section{Discussion}

Previous work has shown that receptor-activated SMADs move to the nucl eus to activate transcription (Chen et al. 1996; Hoodless et al. 1996; Liu et al. 1996; $N$ akao et al. 1997a,b), and their signaling function somehow requires Smad4 (Lagna et al. 1996; Zhang et al. 1996, 1997) with which the receptor-activated SMADs form a complex (Lagna et al. 1996). By examining the requirement of Smad4 in three basic steps of the SMAD pathway, namely, nuclear translocation, binding to DNA, and transcriptional activation, the present study sheds light into the role of Smad4 in this process. The evidence presented here suggests that Smad4 is dispensable for nuclear transl ocation of receptor-activated SMADs, but it plays a rolein their binding to DN A and is essential for their ability to activate transcription.

Nuclear translocation of Smad4 by receptor-activated SMADs

Translocation of receptor-regulated SMADs into the nucleus is a highly controlled process. Phosphorylation of Smad1 at carboxy-terminal sites by the BM P receptor (Kretzschmar et al. 1997a) and phosphorylation of Smad2 at similar sites by the TGF $\beta$ receptor (M acias-Silva et al. 1996) mediate translocation of these SMADs into the nucleus, whereas phosphorylation of Smadl by mitogenactivated protein (MAP) kinase in response to mitogenic factors inhibits nuclear translocation (Kretzschmar et al. 1997b). Phosphorylation by TGF $\beta$ family receptors al so endows SM ADs with the ability to associate with Smad4 (Kretzschmar et al. 1997a). Because Smad4 is required for signal transduction by diverse SMAD pathways, it was possible that the association with Smad4 might mediate 
A

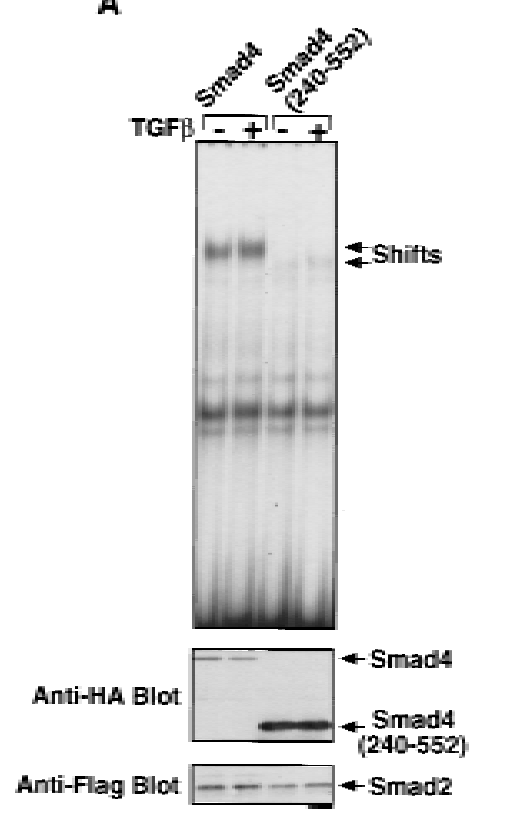

B

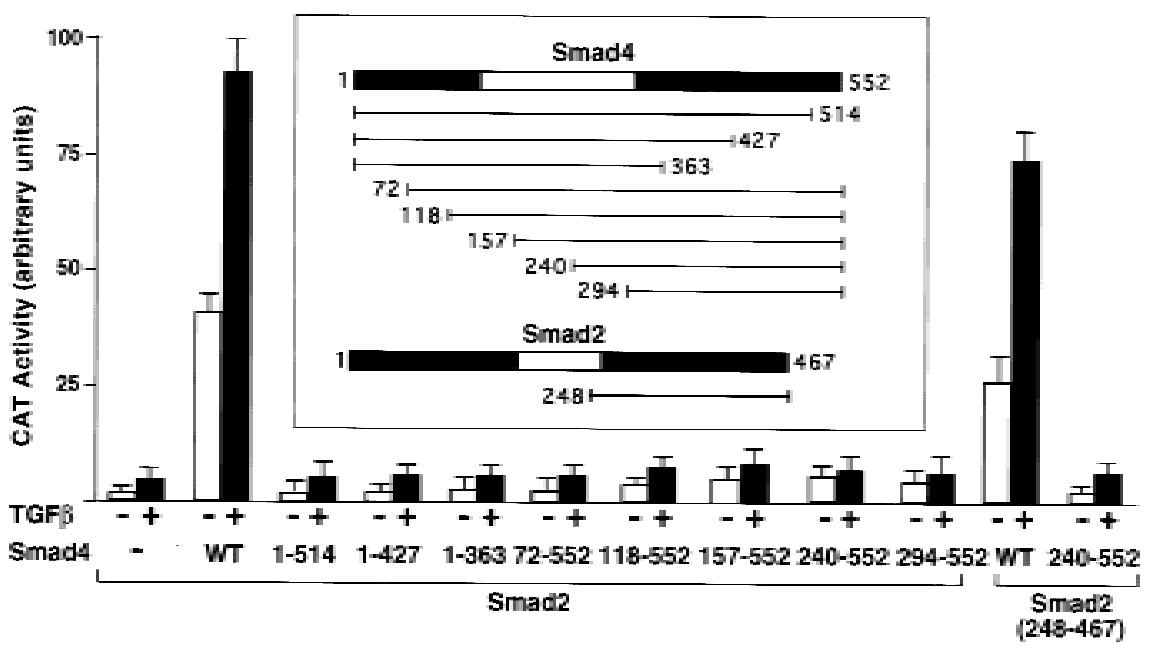

Figure 6. (A) The amino-terminal region of Smad4 is required for DN A binding by the ternary complex. SW480.7 cells were cotransfected with M yc-FAST-1, Flag-Smad2, and either Smad4 or Smad4(240-552), both tagged with the HA epitope. Cells were treated with TGF $\beta$ as indicated. Gel shift experiment was performed with whole cell extracts. The expression level of Flag-Smad2, Smad4, and Smad4(240-552) was analyzed by immunoblotting with antibodies against the Flag or HA epitopes. (B) Both the $\mathrm{N}$ and the $\mathrm{C}$ domains of Smad4 are required to activate the A 3CAT reporter gene. SW 480.7 cells were cotransfected with A3CAT, FAST-1, the indicated full length or truncated Smad4 and Smad2 constructs. Cells were treated with TGF $\beta$, and CAT activity was analyzed.

nuclear transl ocation of receptor-activated SM ADs. Investigation of this question in the present studies by use of the Smad4-deficient cell line SW480.7 clearly indicates that Smad4 is not required for the nuclear translocation of Smad1 or Smad2 in response to their respective agonists. Nuclear translocation of receptor-activated SM ADs is cl early observed under these conditions and is not further enhanced by transfection of Smad4. Furthermore, a Smad4 construct containing an amino-terminal epitope tag is cytoplasmic and remains in the cytoplasm upon BM P or TGF $\beta$ stimulation when transfected al one. When cotransfected with receptor-regulated SMADs, this Smad4 construct is translocated into the nucleus. These results suggest that receptor-activated SMADs can translocate into the nucleus independently of Smad4 and can take Smad4 into the nucleus after associating with it in the cytoplasm.

\section{Formation of a ternary complex}

Is Smad4 part of a transcriptional complex with receptorregulated SMADs? To address this question, we have reconstituted in mammalian cells the FAST-1-dependent transcriptional response described by Whitman and colleagues in Xenopus (Chen et al. 1996). By use of gel mobility shift assays, it was inferred previously that upon activation by the receptor, Smad2 associates with FAST - 1 in the nucl eus (Chen et al . 1996). By transfecting FAST -1 and Smad 2 into T GF $\beta$ responsive lung epithelial cells, we provide evidence for this interaction on the basis of coimmunoprecipitation of a Smad2/FAST-1 complex. Using a panel of Smad2 and FAST-1 deletion mutants, we have determined that the $C$ domains of the two proteins mediate this interaction. In FAST-1, this Smad2-binding domain is separate from the previously identified DNA-binding domain (Chen et al. 1996). In Smad2, the C domain is al so involved in the formation of homo-oligomers and in the interaction with Smad4 (Hata et al. 1997; Wu et al. 1997). The C domain is highly conserved among SMADs and its tertiary structure is known in Smad4 (Shi et al. 1997). The structure of the Smad4 C domain has several solvent-exposed regions that are conserved in Smad2 and may be involved in interactions with other proteins. One of these proteins, in the case of Smad2, may be FAST-1.

Formation of the Smad2/FAST-1 complex in response to TGF $\beta$ does not require Smad4 and is not enhanced by overexpression of Smad4, as determined in Smad4-deficient cells. When Smad4 is present, however, it forms a ternary complex with Smad2 and FAST - 1 , as determined by coimmunoprecipitation of the three proteins. The interaction of Smad4 with FAST-1 requires Smad2. The evidence, therefore, suggests that upon phosphorylation by the TGF $\beta$ receptor, Smad2 associates with Smad4 forming a complex that moves into the nucleus where it binds FAST -1. Recently, Chen et al. (1997) al so observed that Smad4 is in a complex with FAST-1 and Smad2 from injected Xenopus embryos. 
A

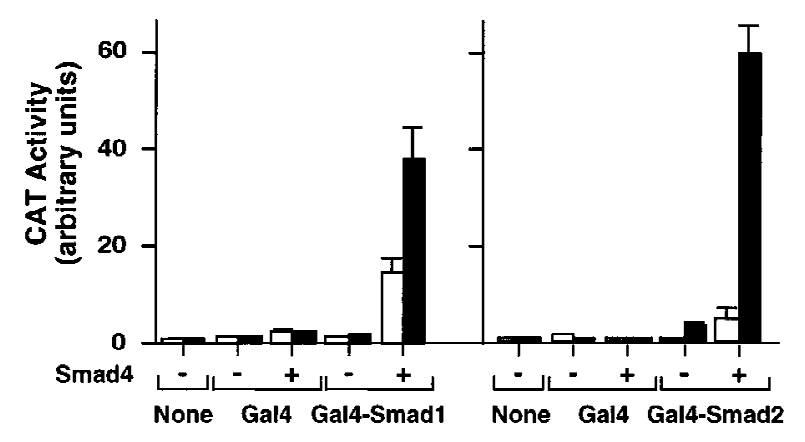

B

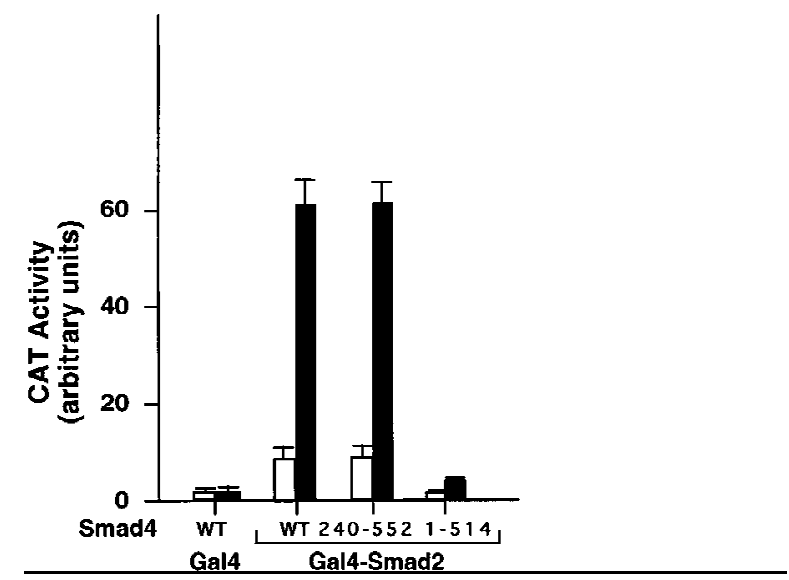

Figure 7. Ligand-induced transcriptional activity of GAL4Smad1 and GAL4-Smad2 depends on the C domain of Smad4. SW480.7 cells were cotransfected with GAL4-Smad1, GAL4Smad2, wild-type Smad4, Smad4(240-552), or Smad4(1-514) along with the GAL4 reporter gene GIEIBCAT (Lillie and Green 1989). Cells were incubated with 2 nM BMP4 (ם) in A (left) or without $(\square)$, or with 500 pM TGF $\beta$ in A (right) and B, as indicated, and CAT activity was then analyzed.

Interaction with DNA: Involvement of the Smad4 $\mathrm{N}$ domain

Our gel mobility shift assays and A 3 CAT reporter gene assays indicate that formation of the Smad2/Smad4/ FAST-1 complex is essential for optimal binding to the ARE and transcriptional activation of A3CAT. The DN A-bound complex detected in the presence of Smad2, Smad4, and FAST-1 contains these three proteins, as determined by gel mobility supershift assays with the appropriate antibodies. Little or no TGF $\beta$-inducible AREbinding complex or A3CAT activation were observed in cells expressing Smad2 and FAST -1 but devoid of Smad4. Smad4 is therefore required for optimal binding of the ternary complex to the ARE.

Previous work has shown that the $C$ domain of Smad4 is sufficient for an interaction with receptor-activated Smad2 (Hata et al. 1997). The present results, however, indicate that the $\mathrm{C}$ domain of Smad4 is not sufficient to promote binding to the ARE and activation of A 3 CAT. The amino-terminal regi on of Smad4 is required for optimal binding of the ternary complex to DNA. The inability of the Smad4 C domain to activate transcription in SW480.7 cells was observed not only with the A 3 CAT reporter but also with the TGF $\beta$-responsive p3TP-luciferase reporter ( $F$. Liu et al., unpubl.). A previous study showed that transfection of a Smad4 C domain can lead to transcriptional activation of p3TP-luciferase in R1B/ L17 cells that contain wild-type of Smad4 (Hata et al. 1997). It should be noted that these results are not incompatible because the Smad4 C domain could act in $\mathrm{R}-1 \mathrm{~B} / \mathrm{L} 17$ cells by associating with the endogenous Smad4.

The mechanism by which Smad4 promotes interaction of the ternary complex with DNA remains to be elucidated. FAST-1 can bind to ARE directly in yeast (Chen et al. 1996), and FAST-1/ARE complexes have been detected with whole cell extracts from FAST-1transfected cells (Chen et al . 1996; F. Liu et al., unpubl.). Therefore, Smad4 might act by enhancing the intrinsic DN A-binding activity of FAST-1 in the ternary complex. Although Smad4 does not appear to stabilize the interaction between FAST-1 and Smad2 in solution, we cannot exclude the possibility that the Smad4 N domain stabilizes the interaction between FAST -1 and Smad 2 on DN A. Alternatively, one attractive possi bility is that the Smad4 N domain has affinity for DNA. This possibility is supported by the recent observation that the homologous amino-terminal regi on of Drosophila $M$ ad can bind directly to a specific DN A sequence in the promoter of the D pp target gene vestigial (Kim et al. 1997). Although we were unable to detect DN A binding by Smad4 al one, this could be as a result of a low affinity of Smad4 for DNA. Smad4 might contact DNA only after being recruited into the ternary complex with Smad2 and FAST1. These possibilities warrant further investigation.

The Smad4 N domain has been shown to inhibit the ability of the $\mathrm{C}$ domain to associate with Smad2 (Hata et al. 1997). The Smad4 N domain, however, has been shown recently to enhance agonist-dependent signaling (de Caestecker et al . 1997). In light of this and the present results, it is possible that Smad4 $\mathrm{N}$ and $\mathrm{C}$ domains interact with each other in the basal state in a reciprocally inhibitory fashion.

Trancriptional activation requiring the Smad4 C domain

If the DNA-binding requirement of a SMAD complex is bypassed, is Smad4 still required for transcriptional activation? We investigated this question by fusing the GAL4 DNA-binding domain to receptor regulated SM ADs to provide DN A-binding activity independent of FAST-1 or other cofactors. In cells containing endogenous Smad4, these GAL4-Smad1 and GAL4-Smad2 fusions can mediate agonist-dependent activation of a GAL4 reporter gene (Liu et al. 1996; Hayashi et al . 1997). In Smad4 deficient SW480.7 cells, however, these constructs are inactive and do not mediate transcriptional 
activation in response to BM P4 or T GF $\beta$. Transcriptional activation under these conditions is rescued by cotransfection of full-length Smad4 and, importantly, by cotransfection of the Smad4 C domain. Thus, when the DNA-binding function is supplied by an ectopic DNAbinding domain, receptor-activated SMADs still require Smad4 for transcriptional activation. In this case, the $C$ domain of Smad4 is sufficient to provide this rate-limiting function. It is possible that the Smad4 C domain, either alone or jointly with the associated $C$ domain of Smads 1 or 2 , activates basal transcription machinery.

In concl usion, the present results shed light on the role of Smad4 in the SM AD-signaling pathway. Collectively, the evidence suggests a model (Fig. 8) in which a receptor-regulated SM AD, such as Smad1 or Smad2, moves into the nucleus where it can associate with a sequencespecific DNA-binding protein such as FAST-1 without requiring Smad4. Association of Smad2 with Smad4, however, presumably in the cytoplasm, and formation of a ternary complex with FAST-1 in the nucleus are required for optimal binding of this complex to DNA and for transcriptional activation. The contributions to DN A binding and transcriptional activation appear to be made through distinct regions of Smad4. The dual function of Smad4 in transcriptional regulation highlights its central role in TGF $\beta$ signaling.

\section{Materials and methods}

\section{Constructs}

Smad2 cDN A (GenBank accession no. AF027964) was obtained by sequencing and ligation of human EST cDN A clones. GAL4Smad2 was constructed by inserting the human Smad2 CDN A

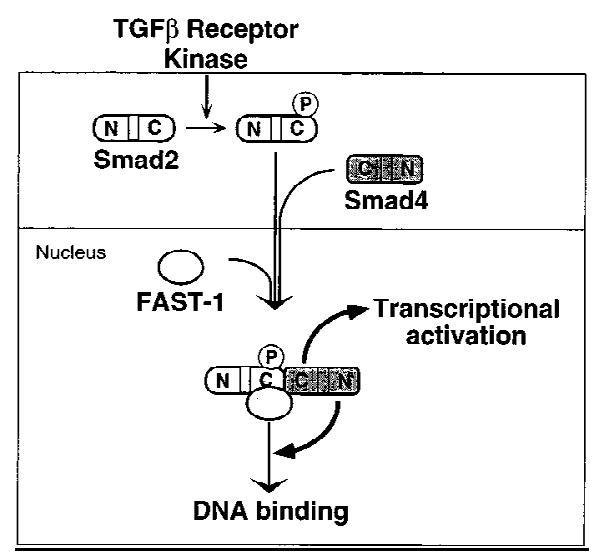

Figure 8. A model depicting the participation of Smad4 in a transcriptional complex with Smad2 and FAST -1, extending the previous model of Chen et al. (1996). U pon phosphorylation by the activated receptor, Smad2 translocates to the nucleus. Smad4 associates with Smad2 through their $C$ domains but is not required for this translocation. In the nucleus, the Smad2/ Smad4 complex associates with FAST-1. In this ternary complex, the $\mathrm{N}$ domain of Smad4 promotes binding to DNA, whereas the $C$ domain of Smad4 is essential for activation of transcription. into the pSG 424 vector (Sadowski and Ptashne 1989). Smad3 CDNA and the various Myc tagged FAST-1 derivatives were constructed in the CS2 vector (T urner and Weintraub 1994). All other constructs have been described (Liu et al. 1996; Hata et al. 1997; Kretzschmar et al. 1997a).

Immunofluorescence

SW480.7 cells were transfected with lipofectin reagent (GIBCO $B R L$ ) for $20 \mathrm{hr}$ and then plated into chamber slides. BMP or TGF $\beta$ stimulation was provided by cotransfecting the activated BM P type I receptor, BM PR-IA (Q233D) (Hoodl ess et al. 1996) or the activated TGF $\beta$ type I receptor, T $\beta$ R-I(T 204D) (Wieser et al. 1995), and incubated with 2 nM BM P4 or 1 nM TGF $\beta 1$ for $1 \mathrm{hr}$. Cells were then fixed by methanol/acetone. Immunostaining was performed by incubation with the M 2 Flag antibody (Eastman Kodak) at $1 \mu \mathrm{g} / \mathrm{ml}$ for $1 \mathrm{hr}$ followed by incubation with the FITC-conjugated goat anti-mouse antibody (1:100) (Jackson Immunologicals) for $1 \mathrm{hr}$.

Immunoprecipitation and immunoblot assay

R1B/L17 and COS cells were transfected with DEAE-dextran, and SW480.7 cells were transfected with lipofectin. Cells were induced with $500 \mathrm{pm}$ TGF $\beta 1$ for $1 \mathrm{hr}$ and then lysed in $1 \mathrm{ml}$ of TNE buffer [10 mm Tris (pH 7.8), $150 \mathrm{~mm} \mathrm{NaCl}, 1 \mathrm{~mm}$ EDTA, $1 \%$ N P-40] in the presence of protease inhibitors. Immunoprecipitation was performed by incubation with the M 2 Flag monoclonal antibody (Eastman Kodak) or with 9E10 M yc monoclonal antibody (Santa Cruz Biotechnology) for $1 \mathrm{hr}$. Immunoprecipitates were separated in an 8\% SDS-PAGE (except for Fig. 3B, in a $14 \%$ SDS-PAGE) and transferred to a PVDF membrane. Immunoblotting was performed by use of antibodies against the epitopes Flag, Myc, or HA (12CA5 antibody, Boehringer M annheim), followed by incubation with the HRP-conjugated goat anti-mouse antibody and detected by chemiluminescence (Amersham).

To detect the ternary complex, transfected COS cells were lysed in $1 \mathrm{ml}$ of TNE buffer and immunoprecipitated with agarose-coupled M2 Flag antibody for $3.5 \mathrm{hr}$. The precipitates were eluted twice with $250 \mu \mathrm{g} / \mathrm{ml}$ of Flag peptide (Eastman Kodak) and the eluate diluted with $0.8 \mathrm{ml}$ of TNE buffer, immunopreci pitated with anti-M yc antibody for $6 \mathrm{hr}$, and subjected to antiHA immunoblotting.

Gel mobility shift and supershift assay

SW480.7 cells were transfected with lipofectin and treated with TGF $\beta$ for $18 \mathrm{hr}$. N ucl ear extracts were prepared by resuspending cells in a hypotonic buffer containing $10 \%$ glycerol, $20 \mathrm{~mm}$ HEPES (pH 7.9), $0.1 \mathrm{~mm}$ EDTA, $50 \mathrm{~mm} \mathrm{KCl}, 2 \mathrm{~mm}$ DTT, 0.15 $\mathrm{mm}$ spermine, $0.5 \mathrm{~mm}$ spermidine, and protease and phosphatase inhibitors. Cell suspensions were frozen in liquid nitrogen and then thawed on ice. The nuclei fraction was recovered by centrifugation and then incubated on ice with a hypertonic buffer containing $20 \%$ glycerol, $20 \mathrm{~mm}$ HEPES (pH 7.9), $0.1 \mathrm{~mm}$ EDTA, $600 \mathrm{~mm} \mathrm{KCl}$, and $2 \mathrm{~mm}$ DTT with protease and phosphatase inhibitors. After centrifugation, the supernatant was recovered as nuclear extract. Whole cell extract was prepared by freezing cell pellet in liquid nitrogen and lysis of the frozen cell pellet in a buffer containing $10 \mathrm{~mm}$ HEPES (pH 7.9), $300 \mathrm{~mm}$ $\mathrm{N} \mathrm{aCl}, 0.1 \mathrm{~mm}$ EGTA, $20 \%$ glycerol, and $0.2 \%$ N P-40 with protease inhibitors and phosphatase inhibitors. DNA-binding assays were performed essentially as described (Huang et al. 1995) with $1 \mathrm{ng}$ of radiolabeled ARE probe. For antibody supershift assays, extracts were incubated for $10 \mathrm{~min}$ in binding buffer, then $15 \mathrm{~min}$ with the probe, and $10 \mathrm{~min}$ with antibodies. DN A- 
protein complexes were resolved on a $4 \%$ (40:1) polyacrylamide gels containing $1 \%$ glycerol.

\section{CAT assays}

SW480.7 cells or R1B/L17 cells were transfected with DEAEdextran and treated with 2 nM BM P4 (Genetics Institute), $2.5 \mathrm{~nm}$ activin A ( $\mathrm{N}$ ational Hormone and Pituitary Program, $\mathrm{N}$ ational Institute of Diabetes and Digestive Kidney Diseases), or $500 \mathrm{pm}$ TGF $\beta 1$ (R\&D Systems) for 18-22 hr. CAT activity was quantitated by scintillation counting or Phosphorlmager analysis.

\section{Acknowledgments}

We gratefully acknowledge M. Whitman for the FAST -1 CDN A and the A 3 CAT reporter gene, Y. Zhang and R. Derynck for the Smad3 CDNA, H. Ge, C. Fasching, and E. Stanbridge for SW480.7 cells, Genetics Institute for BM P4, the N ational Hormone and Pituitary Program for activin, K. M anova for assistance with cell imaging, A. Hata and R.S. Lo for constructs, and J. Doody, R.S. Lo, D. Wotton, Y.G. Shi, C. Zhang, and Y.-G. Chen for hel pful discussions and assistance. This work was supported by grants from the $\mathrm{N}$ ational Institutes of Health to J.M. and to the Memorial Sloan-Kettering Cancer Center. F.L. and C.P. are recipients of postdoctoral fellowships from the Jane Coffin Childs Memorial Fund for M edical Research and the International Agency for Research on Cancer, respectively. J.M. is an investigator of the Howard Hughes Medical Institute.

The publication costs of this article were defrayed in part by payment of page charges. This article must therefore be hereby marked "advertisement" in accordance with 18 USC section 1734 solely to indicate this fact.

\section{References}

Baker, J. and R.M. Harland. 1996. A novel mesoderm inducer, $\mathrm{mM}$ adr-2, functions in the activin signal transduction pathway. Genes \& Dev. 10: 1880-1889.

Barrett, M.T., M. Schutte, S.E. Kern, and B.J. Reid. 1996. Allelic loss and mutational analysis of the DPC 4 gene in esophageal adenocarcinoma. Cancer Res. 56: 4351-4353.

Cárcamo, J., F.M.B. Weis, F. Ventura, R. Wieser, J.L. Wrana, L. Attisano, and J. Massagué. 1994. Type I receptors specify growth inhibitory and transcriptional responses to TGF- $\beta$ and activin. Mol. Cell Biol. 14: 3810-3821.

Chen, X., M.J. Rubock, and M. Whitman. 1996. A transcriptional partner of MAD proteins in TGF- $\beta$ signaling. Nature 383: 691-696.

Chen, X., E. Weisberg, V. Fridmacher, M. Watanabe, G. N aco, and M. Whitman. 1997. Smad4 and FAST -1 in the assembly of activin-responsive factor. Nature 389: 85-89.

Datto, M.B., Y. Yu, and X.-F. Wang. 1995. Functional analysis of the transforming growth factor $\beta$ responsive elements in WAF1/Cip1/p21 promoter. J. Biol. Chem. 270: 28623-28628.

de Caestecker, M .P., P. Hemmati, S. Larisch-Bloch, R. Ajmera, A.B. Roberts, and R.J. Lechleider. 1997. Characterization of functional domains within Smad4/DPC4. J. Biol. Chem. 272: 13690-13696.

Derynck, R. and Y. Zhang. 1996. Intracellular signaling: The Mad way to do it. Curr. Biol. 6: 1226-1229.

Eppert, K., S.W. Scherer, H. Ozcelik, R. Pirone, P. Hoodless, H. Kim, L.-C. Tsui, B. Bapat, S. Gallinger, I.L. Andrulis, G.H. Thomsen, J.L. Wrana, and L. Attisano. 1996. MADR2 maps to $18 \mathrm{q} 21$ and encodes a TGF $\beta$-regulated MAD-related pro- tein that is functionally mutated in colorectal carcinoma. Cell 86: $543-552$.

Goyette, M.C., K. Cho, C.L. Fasching, D.B. Levy, K.W. Kinzler, C. Paraskeva, B. Vogelstein, and E.J. Stanbridge. 1992. Progression of colorectal cancer is associated with multiple tumor suppressor gene defects but inhibition of tumorigenicity is accomplished by correction of any single defect via chromosome transfer. Mol. Cell. Biol. 12: 1387-1395.

Graff, J.M., A. Bansal, and D.A. Melton. 1996. Xenopus Mad proteins transduce distinct subsets of signals for the TGF $\beta$ superfamily. Cell 85: 479-487.

Hahn, S.A., M. Schutte, A.T.M.S. Hoque, C.A. Moskaluk, L.T. da Costa, E. Rozenblum, C.L. Weinstein, A. Fischer, C.J. Yeo, R.H. Hruban, and S.E. Kern. 1996. DPC4, a candidate tumor suppressor gene at human chromosome 18q21.1. Science 271: 350-353.

Hannon, G.J. and D. Beach. 1994. p15IN K4B is a potential effector of TGF- $\beta$-induced cell cycle arrest. Nature 371: 257261.

Hata, A., R.S. Lo, D. Wotton, G. Lagna, and J. Massagué. 1997. Mutations increasing autoinhibition inactivate the tumour suppressors Smad2 and Smad4. Nature 388: 82-86.

Hayashi, H., S. Abdollah, Y. Qiu, J. Cai, Y.Y. Xu, B.W. Grinnell, M.A. Richardson, J.N . Topper, M .A. Gimbrone, J.L. Wrana, and D. Falb. 1997. The MAD-related protein Smad7 associates with the TGF $\beta$ receptor and functions as an antagonist of TGF $\beta$ signaling. Cell 89: 1165-1173.

Hoodless, P.A., T. Haerry, S. Abdollah, M. Stapleton, M.B. O'Connor, L. Attisano, and J.L. Wrana. 1996. MADR1, a MAD-related protein that functions in BM P2 signaling pathways. Cell 85: 489-500.

Huang, H.-C., L.C. Murtaugh, P.D. Vize, and M. Whitman. 1995. Identification of a potential regulator of early transcriptional responses to mesoderm inducers in the frog embryo. EMBO J. 14: 5965-5973.

lavarone, A. and J. Massagué. 1997. Repression of the CDK activator $\mathrm{Cdc} 25 \mathrm{~A}$ and cell-cycle arrest by cytokine TGF- $\beta$ in cells lacking the CDK inhibitor p15. Nature 387: 417-422.

Inagaki, Y., S. Truter, and F. Ramirez. 1994. TGF- $\beta$ stimulates a2(I) collagen gene expression through a cis-acting element that contains an Sp1-binding site. J. Biol. Chem. 269: 1482814834.

Keeton, M.R., S.A. Curriden, A.-J. van Zonneveld, and D. Loskutoff. 1991. Identification of regulatory sequences in the type 1 plasminogen activator inhibitor gene responsive to transforming growth factor $\beta$. J. Biol. Chem. 266: 2304823052.

Kerr, L.D., N .E. Olashaw, and L.M. M atrisian. 1988. Transforming growth factor $\beta 1$ and CAMP inhibit transcription of epidermal growth factor- and oncogene-induced transin RN A. J. Biol. Chem. 263: 16999-17005.

Kim, S.K., Y. Fan, V. Papadimitrakopoulou, G. Clayman, W.N. Hittelman, W.K. Hong, R. Lotan, and L. M ao. 1996. DPC4, a candidate tumor suppressor gene, is altered infrequently in head and neck squamous cell carcinoma. Cancer Res. 56: 2519-2521.

Kim, J., K. Johnson, H.J. Chen, S. Carroll, and A. Laughon. 1997. Drosophila Mad binds to DNA and directly mediates activation of vestigial by Decapentaplegic. Nature 388: 304-308.

Kretzschmar, M., F. Liu, A. Hata, J. Doody, and J. Massagué. 1997a. The TGF- $\beta$ mediator Smad1 is directly phosphorylated and functionally activated by the BM P receptor kinase. Genes \& Dev. 11: 984-995.

Kretzschmar, M., J. Doody, and J. Massagué. 1997b. Opposing BMP and EGF signaling pathways converge on the TGF $\beta$ family mediator Smad1. Nature 389: 618-622. 
Lagna, G., A. Hata, A. Hemmati-Brivanlou, and J. Massagué. 1996. Partnership between DPC4 and SMAD proteins in TGF $\beta$ signaling pathways. Nature 383: 832-836.

Lechleider, R.J., M.P. de Caestecker, A. Dehejia, M.H. Polyme ropoulos, and A.B. Roberts. 1996. Serine, phosphorylation, chromosomal localization and TGF $\beta$ signal transduction by human bsp-1. J. Biol. Chem. 271: 17617-17620.

Lillie, J.W. and M.R. Green. 1989. Transcription activation by the adenovirus E1A protein. Nature 338: 39-44.

Liu, F., A. Hata, J. Baker, J. Doody, J. Cárcamo, R. Harland, and J. Massagué. 1996. A human Mad protein acting as a BM Pregulated transcriptional activator. Nature 381: 620-623.

Macias-Silva, M., S. Abdollah, P.A. Hoodless, R. Pirone, L. Attisano, and J.L. Wrana. 1996. MADR2 is a substrate of the TGF $\beta$ receptor and phosphorylation is required for nuclear accumulation and signaling. Cell 87: 1215-1224.

Massagué, J., A. Hata, and F. Liu. 1997. TGF $\beta$ signaling through the Smad pathway. Trends Cell Biol. 7: 187-192.

Nagatake, M., Y. Takagi, H. Osada, K. U chida, T. Mitsudomi, S. Saji, K. Shimokata, T. Takahashi, and T. Takahashi. 1996. Somatic in vivo alterations of the DPC 4 gene at $18 \mathrm{q} 21$ in human lung cancers. Cancer Res. 56: 2718-2720.

Nakao, A., E. Röijer, T. Imamura, S. Souchelnytskyi, G. Stenman, C.-H. Heldin, and P. ten Dijke. 1997. Identification of Smad2, a human Mad-related protein in the transforming growth factor- $\beta$ signaling pathway. J. Biol. Chem. 272: 28962900.

Nakao, A., T. Imamura, S. Souchel nytskyi, M. Kawabata, A. Ishisaki, E. Oeda, K. Tamaki, J.-i. Hanai, C.-H. Heldin, K. Miyazono, and P. ten Dijke. 1997. TGF- $\beta$ receptor-mediated signaling through Smad2, Smad3 and Smad4. EMBO J. 16: $5353-5362$.

Newfeld, S.J., E.H. Chartoff, J.M. Graff, D.M. M elton, and W.M. Gelbart. 1996. M others against dpp encodes a conserved cytoplasmic protein required in DPP/TGF $\beta$ responsive cells. Development 122: 2099-2108.

Pietenpol, J.A., R.W. Stein, E. Moran, P. Yacuik, R. Schlegel, R.M. Lyons, R.M. Pittelkow, K. Münger, P.M. Howley, and H.L. M oses. 1990. TGF- $\beta 1$ Inhibition of c-myc transcription and growth in keratinocytes is abrogated by viral transforming protein with pRB binding domains. Cell 61: 777-785.

Reynisdóttir, I., K. Polyak, A. lavarone, and J. Massagué. 1995. Kip/Cip and Ink4 Cdk inhibitors cooperate to induce cell cycle arest in response to TGF- $\beta$. Genes \& Dev. 9: 18311845.

Riggins, G.J., S. Thiagalingam, E. Rozenblum, C.L. Weinstein, S.E. Kern, S.R. Hamilton, J.K.V. Willson, S.D. Markowitz, K.W. Kinzler, and B. Vogelstein. 1996. Mad-related genes in the human. Nature Genet. 13: 347-349.

Rossi, P., G. Karsenty, A.B. Roberts, N.S. Roche, M.B. Sporn, and B. de Crombrugghe. 1988. A nuclear factor 1 binding site mediates the transcriptional activation of a type I collagen promoter by transforming growth factor- $\beta$. Cell 5: 405-414.

Sadowski, I. and M. Ptashne. 1989. A vector for expressing GAL4(1-147) fusion in mammalian cells. Nucleic Acid Res. 17: 7539 .

Savage, C., P. Das, A. Finelli, S.R. Townsend, C.-Y. Sun, S.E. Baird, and R.W. Padgett. 1996. Caenorhabditis el egans genes sma-2, sma-3 and sma-4 define a conserved family of transforming growth factor $\beta$ pathway components. Proc. Natl. Acad. Sci. 93: 790-794.

Schutte, M., R.H. Hruban, L. Hedrik, K.R. Cho, G.M. N adasdy, C.L. Weinstein, G.S. Bova, W.B. Isaacs, P. Cairns, H. N awroz, D. Sidransky, C.A. Casero, P.S. M eltzer, S.A. Hahn, and S.E. Kern. 1996. DPC4 gene in various tumor types. Cancer Res. 56: 2527-2530.
Sekelsky, J.J., S.J. Newfeld, L.A. Raftery, E.H. Chartoff, and W.M. Gel bart. 1995. Genetic characterization and cloning of Mothers against dpp, a gene required for decapentaplegic function in Drosophila melanogaster. Genetics 139: 13471358.

Shi, Y., A. Hata, R.S. Lo, J. Massagué, and N.P. Pavletich. 1997. A structural basis for mutational inactivation of the tumour suppressor Smad4. Nature 388: 87-93.

Thomsen, G. 1996. Xenopus mothers against decapentaplegic is an embryonic ventral izing agent that acts downstream of the BM P-2/ 4 receptor. Development 122: 2359-2366.

Topper, J.N., J. Cai, Y. Qiu, K.R. Anderson, Y.Y. Xu, J.D. Deeds, R. Feeley, C.J. Gimeno, E.A. Woolf, O. Tayber, G.G. Mays, B.A. Sampson, F.J. Schoen, M.A. Gimbrone, and D. Falb. 1997. Vascular MADs: Two novel MAD-related genes selectively inducible by flow in human vascular endothelium. Proc. Natl. Acad. Sci. 94: 9314-9319.

Turner, D.L. and H. Weintraub. 1994. Expression of achaetescute homolog 3 in Xenopus embryos converts ectodermal cells to a neural fate. Genes \& Dev. 8: 1434-1447.

U chida, K., M. Nagatake, H. Osada, Y. Yatabe, M. Kondo, T. Mitsudomi, A. Masuda, T. Takahashi, and T. Takahashi. 1996. Somatic in vivo al terations of the JV18-1 gene at 18q21 in human lung cancers. Cancer Res. 56: 5583-5585.

Watanabe, T.K., M. Suzuki, Y. Omori, H. Hishigaki, M. Horie, N. Kanemoto, T. Fujiwara, Y. N akamura, and E. Takahashi. 1997. Cloning and characterization of a novel member of the human M ad gene family (M ADH6). Genomics 42: 446-451.

Weis-Garcia, F. and J. Massagué. 1996. Complementation between kinase-defective and activation-defective TGF- $\beta$ receptors reveals a novel form of receptor cooperativity essential for signaling. EMBO J. 15: 276-289.

Wiersdorff, V., T. Lecuit, S.M. Cohen, and M. Mlodzik. 1996. $M$ ad acts downstream of Dpp receptors, revealing differential requirement for dpp signaling in initiation and propagation of morphogenesis in the Drosophila eye. Development 122: 2153-2162.

Wieser, R., J.L. Wrana, and J. M assagué. 1995. GS domain mutations that constitutively activate T $\beta R-I$, the downstream signal ing component in the TGF- $\beta$ receptor complex. EMBO J. 14: $2199-2208$.

Wrana, J.L. and L. Attisano. 1996. MAD-related proteins in TGF $\beta$ signaling. Trends Genet. 12: 493-496.

Wrana, J.L., L. Attisano, R. Wieser, F. Ventura, and J. M assagué. 1994. Mechanism of activation of the TGF- $\beta$ receptor. Nature 370: 341-347.

Wu, R.-Y., Y. Zhang, X.-H. Feng, and R. Derynck. 1997. Heteromeric and homomeric interactions correlate with signaling activity and functional cooperativity of Smad3 and Smad4/ DPC4. Mol. Cell. Biol. 17: 2521-2528.

Yingling, J.M., P. Das, C. Savage, C. Zhang, R.W. Padgett, and X.-F. Wang. 1996. Mammalian Dwarfins are phosphorylated in response to TGF- $\beta$ and are implicated in control of cell growth. Proc. Natl. Acad. Sci. 93: 8940-8944.

Zentella, A. and J. Massagué. 1992. TGF- $\beta$ induces myoblast differentiation in the presence of mitogens. Proc. Natl. Acad. Sci. 89: 5176-5180.

Zhang, Y., X.-H. Feng, R.-Y. Wu, and R. Derynck. 1996. Receptor-associated $\mathrm{M}$ ad homologs synergize as effectors of the TGF $\beta$ response. Nature 383: 168-172.

Zhang, Y., T. M usci, and R. Derynck. 1997. The tumor suppressor Smad4/DPC4 as a central mediator of Smad function. Curr. Biol. 7: 270-276. 


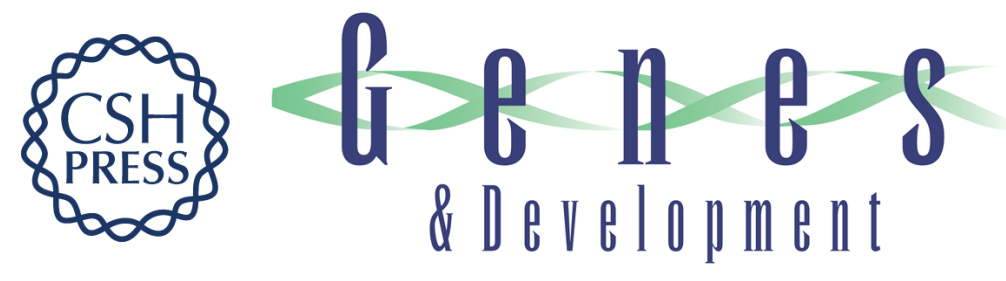

\section{Dual role of the Smad4/DPC4 tumor suppressor in TGF $\beta$-inducible transcriptional complexes}

Fang Liu, Celio Pouponnot and Joan Massagué

Genes Dev. 1997, 11:

Access the most recent version at doi:10.1101/gad.11.23.3157

References

This article cites 57 articles, 29 of which can be accessed free at: http://genesdev.cshlp.org/content/11/23/3157.full.html\#ref-list-1

\section{License}

Email Alerting

Receive free email alerts when new articles cite this article - sign up in the box at the top Service right corner of the article or click here.

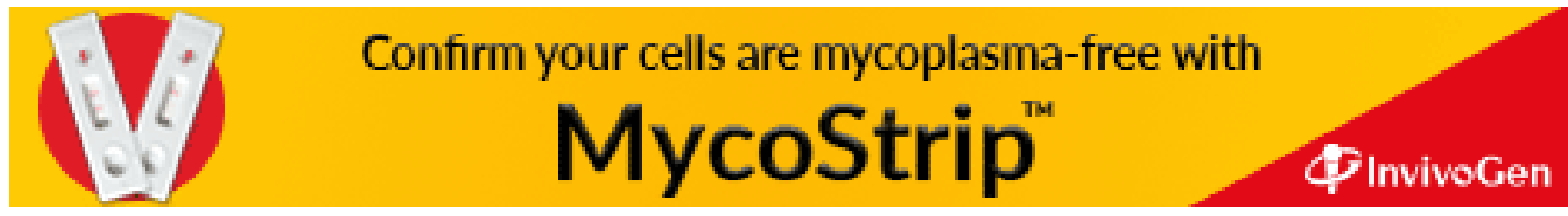

